\title{
PROGRAM KONSELING RESTRUKTURISASI KOGNITIF UNTUK MEREDUKSI KECENDERUNGAN ADIKSI GAME ONLINE PADA REMAJA
}

\author{
Gita Adi Persada', Anne Hafina ${ }^{2}$, Nurhudaya ${ }^{3}$
}

\begin{abstract}
Adolescent who got some addiction of online game has negative cognition. The research goal is to know the tendency profile of online game and to describe counseling hypothetic program of restructuration to reduce tendency of online game. This research used descriptive method where the population and sample is students of SMP Negeri 45 Bandung year $2015 / 2016$ that consist of 323 students and the sample is 137 students. Deciding sample used non probability sampling with purposive sampling. The research instrument used questionnaire that point to addiction tendency aspects of online game. The result showed that: I) generally, the addiction tendency of online game is categorized very low; 2) the result of data processing showed that addiction tendency aspects on mood modification aspect has 10 students is categorized average with percentage of $7,3 \% ; 3$ ) the counseling program plan of cognition restructuration is to reduce addiction tendency of online game on student that focused to reduce some indicator that is categorized low. The recommendation of research is proposed to BK teachers at school and researchers further.
\end{abstract}

Keywords: Addiction Tendency, Counseling of Cognitive Restructuration, Program.

\section{PENDAHULUAN}

Di zaman kehidupan modern ini, segalanya berkembang dan berubah. Perubahan dan perkembangan yang ada pada saat ini ada yang menguntungkan dan ada pula yang merugikan. Harapan akan perubahan yang terjadi pastilah ada, namun yang terjadi pada kenyataannya tidaklah sesuai dengan yang diharapkan. Zaman sekarang mungkin sudah banyak orang yang mengenal dan bahkan tidak sedikit orang yang sudah sering menggunakan Internet dalam kehidupan seharihari sebagi kebutuhan dan hobi. Dari kalangan anak-anak sampai orang tua pun banyak yang menggunakan internet.

Membahas masalah internet, paling tidak sekarang sudah memasuki pembahasan tentang teknologi modern yang terjadi pada masa ini. Di Indonesia sekarang banyak menjamur fasilitas-fasilitas yang mengajak kita untuk

\footnotetext{
${ }^{1}$ Program Studi Bimbingan dan Konseling Universitas Pendidikan Indonesia; gita.adi@student.upi.edu.

2 Program Studi Bimbingan dan Konseling Universitas Pendidikan Indonesia; annehafina@upi.edu.

${ }^{3}$ Program Studi Bimbingan dan Konseling Universitas Pendidikan Indonesia; nurhudaya@upi.edu.
} 
mengetahui berbagai macam teknologi modern, salah satunya internet. Secara garis besar internet merupakan sebuah teknologi yang bersifat membantu baik itu informasi ataupun layanan yang membantu lainnya. Hal ini tentunya merupakan sebuah bantuan bagi bangsa ini apabila dapat mengetahui manfaat dan cara dalam menggunakan teknologi internet dengan benar. Didalam teknologi internet, terdapat banyak aplikasi-aplikasi yang dapat digunakan dalam kehidupan sehari-hari, contohnya google, Yahoo-mail, Facebook, Twitter, Blog, dan salah satunya Game Online.

Game online hadir di Indonesia pada bulan Maret tahun 200I (ligagames.com).Dalam beberapa tahun ini, permainan yang dimainkan secara elektronik atau yang lebih dikenal dengan permainan game online mengalami kemajuan yang pesat dan signifikan, hal ini dapat dilihat dari banyak munculnya warnet (warung internet) game online atau game center untuk bermain game online.

Mungkin sudah tidak asing lagi bila membicarakan "Game Online" atau game yang dimainkan secara Online. Game online ini sangatlah marak dan mungkin sudah dijadikan hobi bagi semua kalangan. Mungkin sebagian dari mereka yang menjadikan game online ini sebagai hobi sangatlah menghibur dan menguntungkan, namun secara tidak langsung dilihat dari fenomena yang ada seseorang sangat terlihat lebih asik dengan dunianya sendiri dalam Game tersebut, tanpa menghiraukan dan mempedulikan lingkungan disekelilingnya.

Game online adalah game atau permainan yang berbasis elektronik dan visual. Game online dimainkan dengan memanfaatkan media visual elektronik. Banyak sekali macam game atau peramainan yang terdapat di Game Online diantaranya, Point Blank, Counter Strike, Ragnarock, Ayo Dance dan masih banyak sekali game yang terdapat di game online.

Game online pada dasarnya diciptakan untuk menghibur para penggunannya terutama seseorang yang menyukai petualangan dan aksi-aksi yang tidak bisa dilakukan dalam kehidupan nyata. Sebenarnya setiap orang boleh saja menjadikan game online ini sebagai hobi atau rutinitas, asalkan bisa mengotrol dan bisa memanage waktu bermainnya. Kebanyakan dari mereka para pengguna game online sangat nyaman ketika mereka bermain game online tersebut. Seseorang bisa menghabiskan banyak waktu ketika bermain game online. Selain nyaman di dalam bermain game online penyebab seseorang menyukai game online adalah, terdapat sebuah game yang didalamnya bisa 
membuat penggunanya mendapatkan keuntungan berupa uang, hal ini yang menyebabkan banyak orang menjadi ketagihan dan adiksi terhadap game online.

Seseorang yang mengalami adiksi terhadap game online bisa saja mengorbankan waktu, kesehatan dan keuangan, hal ini dikarenakan kesenangan yang diberikan dalam permainan game online membuat seseorang menjadi banyak mengorbankan segala hal. Berbagai macam pendapat dikemukakan oleh para ahli mengenai adiksi (kecanduan), menurut Yee (2006: 309), menyatakan bahwa adiksi (kecanduan) adalah suatu perilaku yang tidak sehat yang berlangsung terus-menerus yang sulit untuk dihentikan oleh individu yang bersangkutan. Sedangkan menurut Hovart (Yee, 2002) adiksi diartikan sebagai suatu aktivitas atau substansi yang dilakukan berilang-ulang dan dapat menimbulkan akibat atau dampak yang negatif. Griffths (Terry, Szabo, Griffiths, 2003: 489) menambahkan bahwa perilaku adiksi dibatasi untuk penggunaan obat dan konsumsi alkohol, namun baru-baru ini sejumlah perilaku telat ditemukan dalam kegiatan tertentu seperti olahraga, seks, perjudian, video game, dan penggunaan internet. Adiksi bisa terjadi pada penggunaan dan perilaku tertentu apabila dilakukan secara berilang ulang-ulang, begitu juga pada perilaku bermain game online.

Berkaitan dengan pengertian adiksi yang telah dipaparkan oleh para ahli dapat disimpulkan adiksi terhadap game online bisa diartikan sebagai kegiatan yang dilakukan berulang-ulang dalam bermain game online tanpa menghiraukan segala sesuatu yang terjadi disekitarnya dan dapat menimbulkan dampak negatif bagi individu. Jessica (1999) menyatakan bahwa perilaku kecanduan terhadap game online dapat disebabkan oleh ketersediaan dan bertambahnyajenis-jenis game dipasaran yang semakin pesat seiring dengan perkembangan teknologi.

Fase adiksi terhadap bermain game online merupakan keadaan dimana seseorang akan sangat sulit melepas permainan tersebut. Adiksi terhadap game online menimbulkan kerugian yang sangat signifikan, salah satunya adalah seseorang menjadi lupa akan dunia nyatanya.

Game online hampir digemari oleh seluruh kalangan, bukan hanya anakanak dan remaja saja namun terdapat juga penggemar game online dari kalangan orang dewasa. Namun dapat dilihat disekitar kita kebanyakan mayoritas penggemar game online ini berasal dari kalangan remaja. Permainan game online tersebut pun tidak mengenal usia maupun jenis kelamin. Terdapat sebuah penelitian mengenai Game Online Sebanyak 64,45\% remaja laki-laki dan 
47,85\% remaja usia I2-22 tahun yang bermain game online menyatakan bahwa mereka kecanduan terhadap game online (Yee, 2002). Hal ini juga ditegaskan oleh Jones (2003) bahwa kalangan remaja merupakan mangsa pasar game online yang berjumlah cukup besar yaitu sebanyak $56 \%$ pelajar di Amerika bermain game online, sedangkan di Indonesia sendiri sebanyak enam juta orang menggemari game online (Farzana, 2009: 6).

Pada dasar keberadaan game online menimbulkan beberapa hal positif dan hal negatif terhadap seseorang yang dianggap kecanduan dalam bermain game online. Seperti yang ditegaskan oleh Yee (2006: 3I2) bahwa, salah satu motivasi terpenting dalam bermain game online adalah menghilangkan stress. Jika motivasi tersebut berhasil didapatkan pemain, maka pemain akan merasa relaks dan pemain juga akan mendapatkan rasa nyaman. Hal ini tentunya merupakan hal positif yang didapat dalam bermain game online. Dalam bermain game online seseorang akan mendapatkan hal positif apabila tidak berlebihan ketika bermain game onine. Ketika seseorang sudah berlebihan dalam bermain game online tentu akan muncul rasa candu terhadap permainan tersebut, dan pada akhirnya muncul berbagai dampak negatif dari kecanduan bermain game online tersebut. Menurut Yee (2002) menyatakan bahwa akibat yang buruk dari kecanduan terhadap game online adalah masalah dalam kehidupan sehari-hari, seperti masalah akademis, masalah kesehatan, masalah keuangan dan masalah relasi. Selain itu Chen \& Chang (2008: 38) menyatakan bahwa hal negatif akan muncul pada fungsi fisik dan mental seseorang yang bermain game online secara berlebihan, hal negatif tersebut diantara lain menurunya fungsi indra penglihatan dan berat badan menurun serta menghasilkan kebingungan antara kenyataan dan ilusi. Dari beberapa pendapat tersebut dapat disimpulkan bahwa keberadaan game online akan bermanfaat apabila seseorang mengetahui cara yang benar dalam benar dalam bermain game online.

Remaja mungkin bisa dikatakan sebagai kalangan yang paling terpengaruh dengan adanya keberadaan game online. Hal ini dapat terlihat dari kasus-kasus yang sering terjadi di lingkungan sekolah terutama sekolah menengah. Banyak para siswa menengah lebih memilih membolos untuk bermain game online ketimbang untuk belajar disekolah. Hal ini dapat disebabkan oleh berbagai faktor diantaranya, pengaruh dari teman sebaya, masalah di lingkungan keluarga, masalah di sekolah, dan masih banyak lagi faktor-faktor yang membuat seseorang lebih memilih peralihan dengan bermain game online. 
Membahas tentang remaja tentu sangat berbeda dengan membahas tenang anak ataupun dewasa. Asal kata remaja berasal dari bahasa latin "adolensence" yang berarti bertumbuh menjadi dewasa. Istilah adolensece, mempunyai arti yang luas yang mencankup kematangan mental, emosional sosial dan fisik (Hurlock, 1997: 206).

Masa remaja menunjukkan dengan jelas sifat transisi atau peralihan karena remaja belum memeperoleh status dewasa dan tidak lagi memiliki status sebagai anak. Hal ini senanda dengan yang diungkapkan oleh Santrock (2003: 26) bahwa remaja (adolescene) diartikan sebagai masa perkembangan transisi antara masa anak dan dewasa yang mencangkup perubahan biologis, kognitif, dan sosialemosional.

Pada dasarnya alasan seseorang bermain game online adalah mengasyikan dan dapat menghilangkan stress. Hal ini sangat mendukung, bahwa keberadaan game online ini paling berpengaruh terhadap anak pada usia remaja karena pada masa remaja seseorang banyak mengalami situasi dimana memungkinkan seseorang mengalami stress. Karena masa remaja adalah sebuah masa peralihan dari anak-anak menuju dewasa. Tentunya dalam masa ini seorang remaja banyak menemui masalah. Masa remaja juga sering sebut masa pencarian jati diri dalam diri seseorang. Banyak pengaruh positif dan negatif yang mengahampiri, hal ini yang membuat seorang remaja sangatlah mudah terpengaruh.

\section{METODE}

Penelitian yang dilakukan bertujuan untuk mendapatkan gambaran kecenderungan adiksi game online pada siswa SMP yang selanjutnya digunakan sebagai dasar perancangan program konseling restrukturisasi kognitif untuk mereduksi kecenderungan adiksi game online pada remaja dengan menggunakan pendekatan kuantitatif. Pendekatan kuantitatif adalah suatu pendekatan yang digunakan dalam penelitian terhadap sesuatu yang kongkrit, dapat dikasifikasikan, dan terukur.

Metode yang digunakan dalam penelitian ini adalah penelitian deskriptif. Metode deskriptif adalah metode penelitian penelitian yang bertujuan untuk mendeskripsikan suatu keadaan atau fenomena-fenomena dengan apa adanya. Dalam metode ini, peneliti tidak melakukan manipulasi atau perlakuanperlakuan terhadap objek penelitian (Sukmadinata, 2005: 18). 
Dalam penelitian ini metode deskriptif digunakan untuk menggambarkan kecenderungan terhadap game online yang terjadi pada siswa di SMP Negeri 45 Bandung dan mendeskripsikan tentang rancangan program berupa konseling kelompok dengan teknik restrukturisasi kognitif sebagai upaya untuk mereduksi kencenderungan terhadap game online. Populasi data yang diteliti adalah seluruh siswa kelas VIII SMP Negeri 45 Bandung sebanyak 323 siswa yang dibagi dalam 9 kelas.

Teknik pengambilan sampel yang digunakan adalah non probabilty sampling, dengan proposive sampling. Non probabilty sampling adalah pemilihan sampel dengan cara tidak diacak, sedangkan proposive sampling adalah responden yang dijadikan sampel berdasarkan pertimbangan tertentu dari peneliti (Darmawan, 20l3). Peneliti menentukan sampel penelitian dengan pertimbangan sebagai berikut: I) Siswa yang bermain game online. 2) Rekomendasi guru bimbingan dan konseling mengenai siswa yang diduga bermain game online. Selanjutnya peneliti menentukan sampel sesuai pertimbangan tersebut seperti disebutkan pada Tabel I.

Tabel I. Jumlah Sampel Penelitian

\begin{tabular}{ccc}
\hline No & Kelas & Sampel \\
\hline I & VIII A & 8 \\
\hline 2 & VIII B & 4 \\
\hline 3 & VIII C & 9 \\
\hline 4 & VIII D & 13 \\
\hline 5 & VIII E & 27 \\
\hline 6 & VIII F & 21 \\
\hline 7 & VIII G & 17 \\
\hline 8 & VIII H & 19 \\
\hline 9 & VIII I & 19 \\
\hline & Jumlah & 137 \\
\hline
\end{tabular}

Instrumen yang digunakan dalam penelitian ini adalah instrumen yang dirancang sesuai pengembangan dan perumusan teori mengenai adiksi game online. Butiran-butiran pernyataan dalam instrumen merupakan gambaran tentang kecenderungan adiksi game online pada siswa. Angket menggunakan skala Likert yang terdiri atas beberapa opsi alternatif jawaban, yaitu: SL (selalu), S (sering), KK (kadang-kadang), SJ (sangat jarang), HTP (hampir tidak pernah). Dengan kisi-kisi seperti pada Tabel 2. 
Tabel 2. Kisi-Kisi Instrumen Penelitian

\begin{tabular}{|c|c|c|}
\hline $\begin{array}{l}\mathrm{N} \\
\mathrm{O}\end{array}$ & Aspek & Indikator \\
\hline \multirow[t]{4}{*}{1} & \multirow[t]{4}{*}{ Salience } & Bermain game online menjadi keharusan \\
\hline & & Permainan game online mendominasi pikiran \\
\hline & & Permainan game online mendominasi perasaan \\
\hline & & Selalu memikirkan agar bisa bermain game online \\
\hline \multirow[t]{3}{*}{2} & \multirow{3}{*}{$\begin{array}{l}\text { Mood } \\
\text { Modification }\end{array}$} & Merasa senang ketika bermain game online \\
\hline & & $\begin{array}{l}\text { Memanfaatkan bermain game online sebagai penghilang } \\
\text { stress }\end{array}$ \\
\hline & & $\begin{array}{l}\text { Perasaan senang yang dirasakan ketika bermain game } \\
\text { online menguatkan siswa untuk terus bermain game } \\
\text { online. }\end{array}$ \\
\hline \multirow[t]{3}{*}{3} & \multirow[t]{3}{*}{ Tolerance } & $\begin{array}{l}\text { Terjadi peningkatan intensitas waktu dalam bermain } \\
\text { game online }\end{array}$ \\
\hline & & $\begin{array}{l}\text { Merasa senang ketika menambah intensitas waktu } \\
\text { bermain game online. }\end{array}$ \\
\hline & & Tidak bisa mengatur waktu dalam kesehariannya \\
\hline \multirow[t]{3}{*}{4} & \multirow[t]{3}{*}{ Withdrwal } & Merasa cemas ketika tidak bermain game online. \\
\hline & & Menjadi mudah marah ketika tidak bermain game online \\
\hline & & $\begin{array}{l}\text { Lebih senang berdiam diri ketika tidak bisa bermain } \\
\text { game online. }\end{array}$ \\
\hline \multirow[t]{6}{*}{5} & \multirow[t]{6}{*}{ Conflict } & $\begin{array}{l}\text { Adanya konflik dengan teman karena terus bermain } \\
\text { game online. }\end{array}$ \\
\hline & & $\begin{array}{l}\text { Adanya konflik dengan keluarga karena terus bermain } \\
\text { game online. }\end{array}$ \\
\hline & & $\begin{array}{l}\text { Adanya konflik dalam bidang pendidikan karena terus } \\
\text { bermain game online. }\end{array}$ \\
\hline & & $\begin{array}{l}\text { Adanya konflik internal (dalam diri) karena terus } \\
\text { bermain game online }\end{array}$ \\
\hline & & $\begin{array}{l}\text { Aktivitas bermain game online menggangu kegiatan sosial } \\
\text { lainnya. }\end{array}$ \\
\hline & & $\begin{array}{l}\text { Tidak bisa menghentikan kegiatan dalam bermain game } \\
\text { online }\end{array}$ \\
\hline \multirow[t]{2}{*}{6} & \multirow[t]{2}{*}{ Relapse } & $\begin{array}{l}\text { Terus-menerus bermain game online tanpa memikirkan } \\
\text { dampak yang diterima. }\end{array}$ \\
\hline & & Merasa nyaman bermain \\
\hline
\end{tabular}

Adapun penyekoran data dilakukan dengan merujuk kepada penyekoran skala Likert. Pedoman penyekoran yang diadaptasi dari model skala Likert tampak pada Tabel 3. 
Tabel 3. Pedoman Penyekoran

\begin{tabular}{cccccc}
\hline Pernyataan & \multicolumn{5}{c}{ Opsi Alternatif Jawaban } \\
\hline Positif $(+)$ & $\begin{array}{c}\text { SL } \\
\text { (selalu) }\end{array}$ & $\begin{array}{c}\text { S } \\
\text { (sering) }\end{array}$ & $\begin{array}{c}\text { KK } \\
\text { (kadang- } \\
\text { kadang) }\end{array}$ & $\begin{array}{c}\text { SJ } \\
\text { (sangat } \\
\text { jarang) }\end{array}$ & $\begin{array}{c}\text { TP } \\
\text { (tidak } \\
\text { pernah) }\end{array}$ \\
\hline Skor & 5 & 4 & 3 & 2 & I \\
\hline
\end{tabular}

Penentuan skor untuk setiap jawaban dilakukan secara aposteriori, yaitu kemungkinan skor bagi setiap jawaban didasarkan atas hasil uji coba (Subino, 1987: 124). Selanjutnya hasil dari gambaran kecenderungan adiksi game online pada siswa kelas VIII Tahun Ajaran 2015/2016 akan menjadi dasar merancang program konseling restrukturisasi kognitif untuk mereduksi kecenderungan adiksi game online pada remaja yang berada pada kategori sedang, tinggi dan sangat tinggi.

\section{DISKUSI}

Berdasarkan hasil pengumpulan data terhadap kelas VIII di SMP Negeri 45 Bandung Tahun Ajaran 2015/2016, menunjukan tingkat kecenderungan terhadap adiksi game online sebagaimana ditunjukkan pada Tabel 4.

Tabel 4. Gambaran Umum Kecenderungan Adiksi Game Online

\begin{tabular}{ccc}
\hline $\mathrm{N}$ & Valid & $\mathrm{I} 37$ \\
\cline { 2 - 3 } & Missing & 0 \\
\hline Mean & 0,7500 & \\
\hline Median & 0,7500 & \\
\hline Mode & 0,0000 \\
\hline Std. Deviation & 0,4125 \\
\hline Minimum & 0,0000 \\
\hline Maximum & 1,5500 \\
\hline
\end{tabular}

Tabel 4 menunjukan bahwa kecenderungan adiksi game online yang terjadi pada siswa di kelas VIII SMP Negeri 45 Bandung Tahun Ajaran 2015/2016 sebagian besar berada pada kategori sangat rendah, dengan mean sebesar 0.75 . Kategori sangat rendah diartikan sebagai tingakatan yang tidak pernah sama sekali bermain game online dan tidak ada sama sekali aspek-aspek adiksi game online yang dialami. Dapat disimpulkan secara gambaran umum, kecenderungan 
adiksi game online yang dialami siswa kelas VIII di SMP Negeri 45 Bandung Tahun Ajaran 2015/2016 berada pada titik aman dan jauh dari tingkat kencenderungan adiksi game online seperti tampak pada Tabel 5.

Tabel 5. Gambaran Umum Kecenderungan Adiksi Game Online Pada Siswa Kelas VIII SMP Negeri 45 Bandung Tahun Ajaran 20I5/2016

\begin{tabular}{lccccc}
\hline Aspek & $\mathrm{N}$ & Mean & Simpangan Baku & Modus & Median \\
\hline Salience & 137 & 0.57 & 0.34 & 0.67 & 0.55 \\
\hline Mood Modification & 137 & 1.22 & 0.59 & 0.00 & 2.20 \\
\hline Tolerance & 137 & 0.68 & 0.50 & 0.00 & 1.64 \\
\hline Withdrawl & 137 & 0.67 & 0.46 & 0.00 & 1.60 \\
\hline Conflict & 137 & 0.65 & 0.43 & 0.00 & 1.52 \\
\hline Relapse & 137 & 0.70 & 0.56 & 0.00 & 1.68 \\
\hline
\end{tabular}

Tabel 5 menunjukkan bahwa rerata aspek kecenderungan adiksi game online siswa kelas VIII SMP negeri 45 Bandung Tahun Ajaran 2015/2016 berada pada kategori sangat rendah, rendah dan sedang. Nilai rerata tertinggi berada pada aspek mood modification dengan rerata sebesar 1.22 dengan nilai simpangan baku sebesar 0,59, modus sebesar 0,00 dan median 0,9.

Berdasarkan gambaran umum kecenderungan adiksi game online pada siswa kelas VIII SMP Negeri 45 Bandung Tahun Ajaran 2015/2016, maka dirancanglah program konseling restrukturisasi kognitif untuk mereduksi kecenderungan adiksi game online pada remaja yang disusun dalam sistematika: I) Rasional; 2) Deskripsi Kebutuhan; 3) Tujuan; 4) Komponen Program; 5) Rencana Operasional; 6) Pengembangan Tema/Topik; 7) Rencana Pelaksanaan Layanan.

\section{Rasional}

Seseorang bisa menghabiskan banyak waktu ketika bermain game online. Selain nyaman di dalam bermain game online penyebab seseorang menyukai game online adalah, terdapat sebuah game yang didalamnya bisa membuat penggunanya mendapatkan keuntungan berupa uang, hal ini yang menyebabkan banyak orang menjadi ketagihan dan adiksi terhadap game online.

Menurut Brown (1997) perilaku adiksi dapat dijelaskan sebagai dominasi dari sarana (dapat berupa objek atau perilaku) untuk mempertahankan "hedonic tone". Hedonic tone menurut Brown adalah keadaan dimana individu dapat memperpanjang kesenangan (euphoria) atau menghindari ketidaksengan (dysphoria) dalam diri individu. Sedangkan Yee (Lumban, 20I2) menyatakan 
bahwa, perilaku adiksi adalah suatu prilaku yang tidak sehat yang berlangsung terus menerus yang sulit diakhiri oleh individu bersangkutan. Kecanduan terhadap sesuatu bisa dikatakan sebagai adiksi, begitu juga pada game online. Adiksi pada game online bisa terjadi apabila seseorang terus menerus bermain game online. Adiksi game online merupakan suatu kesenangan dalam bermain karena memberi kepuasan tersendiri, sehingga individu yang mengalami adiksi game online akan terus mengulangi kegiatan tersebut.

Dalam kamus besar bahasa Indonesia (KBBI) kecenderungan diartikan sebagai kecondongan atau memiliki keinginan kearah suatu prilaku. Kecenderungan berbeda dengan perilaku, kecenderungan lebih didasarkan sebagai sebuah kecondongan atau keinginan individu melakukan sesuatu.

Kecenderungan adiksi terhadap game online bisa diartikan sebagai kegiatan yang dilakukan berulang-ulang dalam bermain game online tanpa menghiraukan segala sesuatu yang terjadi disekitarnya, pada hakekatnya kecenderungan adiksi terhadap game online diartikan sebagai sebuah kecondongan atau keinginan individu yang mengarah kepada ketergantungan atau kecanduan terhadap game online. Seseorang yang mengalami adiksi terhadap game online bisa saja mengorbankan waktu, kesehatan dan keuangan, hal ini dikarenakan kesenangan yang diberikan dalam permainan game online membuat seseorang menjadi banyak mengorbankan segala hal.

\section{Deskripsi Kebutuhan}

Dalam upaya bimbingan dan konseling untuk mereduksi kecenderungan adiksi game online pada remaja dibutuhkan deskripsi kebutuhan siswa guna merancang program konseling restrukturisasi kognitif untuk mereduksi kecenderungan adiksi game online pada siswa. Deskripsi kebutuhan yang dibutuhkan sebagai berikut.

Pertama, siswa atau remaja membutuhkan bantuan dalam mengurangi/menghilangkan tingkat kesenangan yang berlebihan ketika bermain game online. Kesenangan berlebihan ketika bermain game online yang dialami siswa didasari oleh kognitif negatif yang dialami siswa. Kognitif negatif tersebut berupa sebuah harapan yang ingin dicapai ketika bermain game online, keyakinan dan kesalah pahaman dalam menanggapi keberadaan game online. Kognitif negatif siswa selanjutnya diidentifikasi dan diubah menjadi positif. 
Kedua, remaja selalu menganggap game online sebagai upaya yang efektif untuk menghilangkan stres. Hal ini merupakan kognitif negatif yang dialami siswa. Siswa memerlukan upaya untuk membantu mengubah perspektifnya terhadap game online dan perlu adanya pengalihan kegiatan guna mereduksi kebiasaannya bermain game online ketika berada dalam keadaan stres.

Ketiga, remaja membutuhkan bantuan dalam mengurangi/menghilangkan tingkat kesenangan ketika bermain game online. Kesenangan berlebihan ketika bermain game online yang dialami siswa didasari oleh kognitif negatif yang dialami siswa. Kognitif negatif tersebut berupa sebuah harapan yang ingin dicapai ketika bermain game online, keyakinan dan kesalah pahaman dalam menanggapi keberadaan game online. Kognitif negatif siswa selanjutnya diidentifikasi dan diubah menjadi positif

\section{Tujuan}

Tujuan umum dirancangnya program konseling restrukturisasi kognitif adalah untuk mereduksi kecenderungan adiksi game online pada siswa kelas VIII SMP Negeri 45 Bandung Tahun Ajaran 2015/2016 dengan cara mengubah kognitif negatif siswa terhadap keberadaan game online dan mengubahnya menjadi positif. Sedangkan tujuan khususnya adalah agar: I) Siswa mampu mengurangi atau menghilangkan tingkat kesenangan yang berlebihan ketika bermain game online; 2) Siswa mampu mencari pengalihan dari aktivitas bermain game online ke aktivitas lainnya yang lebih berdampak positif; dan 3) Siswa mampu mengontrol kesenangannya ketika bermain game online sehingga tidak terjadi pengulangan dalam melakukan aktivitas bermain game online.

\section{Komponen Program}

\section{Layanan Responsif}

Layanan reponsif diberikan kepada siswa dengan tingkat kecenderungan adiksi game online dengan kategori tertinggi yang muncul yaitu kategori sedang. Pada kategori sedang siswa berada pada tingkat berkencederungan ke arah adiksi terhadap game online. Hal ini bertujuan untuk mereduksi kecenderungan tersebut sehingga siswa tidak mendapatkan dampak-dampak negatif dari kebiasaannya dalam bermain game online.

Siswa yang berkecenderungan kearah adiksi terhadap game online dilatih untuk merubah kognitif negatif yang ditimbulkan oleh keberadaan game online dan merubanya menjadi positif. Kognitif negatif yang dialami siswa meliputi 
harapan, keyakinan dan kesalahpahaman dalam menanggapi keberadaan game online.

Materi yang dikembangkan dalam layanan responsif mengacu pada indikator yang berada pada kategori sedang, yaitu kesenangan berlebihan yang dirasakan ketika bermain game online, game online menjadi upaya penghilang stres, dan kesenangan yang dialami ketika bermain game online menjadi penyebab siswa mengulang aktivitasnya dalam bermain game online. Pada dasarnya materi yang dikembangkan pada layanan responsif adalah kognitif negatif yang dialami siswa dalam menanggapi keberadaan game online.

Dukungan Sistem

Dukungan sistem merupakan komponen yang dapat membantu dan memfasilitasi keberhasilan pelaksanaan program konseling restrukturisasi kongnitif untuk mereduksi kecenderungan adiksi game online pada siswa. Layanan dukungan sistem yang dilaksanakan meliputi kegiatan kerjasama yang dilakukan dalam pemberian layanan yang melibatkan staf sekolah inti yang terdiri dari kepala sekolah, wali kelas, dan guru mata pelajaran, serta kerjasama dengan orang tua siswa. Kegiatan yang menjadi dukungan sistem dalam pelaksanaan program konseling restrukturisasi kognitif untuk mereduksi kecenderungan adiksi game online pada siswa, yaitu: I) Guru BK melakukan kerjasama dengan wali kelas dan guru mata pelajaran untuk menghimpun berbagai informasi mengenai aktivitas siswa saat kegiatan belajar mengajar; 2) Mengadakan pertemuan rutin dengan orang tua siswa dengan tujuan untuk bertukar informasi mengenai perkembangan siswa; dan 3) Dukungan lingkungan fisik yang meliputi persiapan sarana dan prasarana, seperti rancangan program konseling, pedoman observasi, dan ruang bimbingan dan konseling yang memadai.

\section{SIMPULAN}

Gambaran umum kecenderungan adiksi game online pada siswa kelas VIII di SMP Negeri 45 Bandung Tahun Ajaran 20I5/20I6 sebagian besar berada pada kategori sangat rendah, artinya siswa memang menganggap keberadaan game online hanya sebagai hiburan saja, tidak semata-mata dijadikan kegiatan utama dalam kesehariannya. Namun dari 137 siswa yang menjadi sampel penelitian terdapat beberapa siswa yang berada pada kategori sedang, artinya terdapat 
siswa yang memang membutuhkan penanganan untuk mereduksi kebiasaannya dalam bermain game online.

Program konseling restrukturisasi kognitif dirancang sebagai upaya untuk membantu siswa dalam mereduksi kebiasaan bermain game online. Program konseling restrukturisasi kognitif untuk mereduksi kecenderungan adiksi game online pada siswa telah disusun dan uji kelayakan oleh dosen ahli dan guru bimbingan dan konseling sudah teruji dapat diterapkan untuk membantu siswa dalam mereduksi kecenderungan adiksi game online pada siswa.

Guru bimbingan dan konseling dapat menjadikan rancangan program konseling dengan menggunakan konseling restrukturisasi kognitif untuk mereduksi kecenderungan adiksi game online pada peserta didik. Rancangan program konseling restrukturisasi kognitif selanjutnya dijadikan acuan langkahlangkah untuk melakukan layanan konseling restrukturisasi kognitif untuk mereduksi kecenderungan adiksi game online pada remaja.

Penelitian ini terbatas pada pengujian efektivitas dari teknik konseling restrukturisasi kognitif untuk mereduksi kecenderungan adiksi game online pada remaja, oleh karena itu banyak yang harus dikaji oleh peneliti selanjutnya. Peneliti selanjutnya mencoba merancang desain penelitian mengenai kecenderungan adiksi game online pada jenjang pendidikan yang berbeda, sehingga dapat mengetahui beragam program intervensi di semua jenjang pendidikan dan peneliti selanjutnya disarankan untuk lebih mengkaji keseluruhan aspek-aspek kecenderungan adiksi game online pada siswa dengan memberikan penanganan menggunakan teknik layanan tertentu.

\section{REFERENSI}

Brown, R. I. F. (1997). A theoretical model of the behavioural addictionsapplied to offending. Addicted to crime, 13-65.

Chen, C. Y., \& Chang, S. L. (2008). an exploration of the tendency to online games addiction due to user's liking of design features. Journal of Health and Information, 3(I-4), 38-5I.

Darmawan, D. (20I3). Metode penenlitian kuantitatif. Bandung: Remaja Rosda Karya. 
Depdiknas. (2008). Penataan pendidikan profesional konselor dan layanan bimbingan dan konseling dalam jalur pendidikan formal. Jakarta: Departemen Pendidikan Nasional.

Farzana, A. (2009). I0I Tips \& ide mencegah anak kecanduan game. Yogyakarta: Edukasia.

Hurlock. E. B. (1997). Alih bahasa: Istiwidiyanti. Psikologi perkembangan. Jakarta: Erlangga.

Jessica, M. (1999). History of game online. [Online]. Tersedia: http://tharsis_gate.org/articles/imaginary/history 3.htm. [3 April 20I5].

Jones, S. (2003). Let the games begin: Gaming technology and entertainment among college students. Washington: Pew Internet and American Life Project.

KBBI (Kamus Besar Bahasa Indonesia). Definisi adiksi. [Online]. Tersedia: http://kbbi.web.id/adiksi. [20 Januari 20I5].

KBBI (Kamus Besar Bahasa Indonesia). Definisi kecenderungan. [Online]. Tersedia: http://kbbi.web.id/adiksi. [20 Januari 20I5].

Liga Games. (20II). Game online di Indonesia. [Online]. Tersedia: www.ligagames.com. [23 Desember 2014].

Lumban, T. (20I2). Hubungan kecanduan game online dengan prestasi akademik mahasiswa di fakultas teknik Universitas Indonesia. Skripsi Program Sarjana Reguler Ilmu Keperawatan Universitas Indonesia: Diterbitkan.

Santrock, J. W. (2003). Life-span development. Jakarta: Erlangga.

Szabo, A., \& Griffiths, M. D. (2004). The exercise addiction inventory: A new brief screening tool. Addiction Research and Theory, I2(5), 489-499.

Subino. (1987). Konstruksi dan analisis tes, suatu pengantar kepada teori tes dan pengukuran. Jakarta: LPTK Depdikbud.

Sukmadinata, S, N. (2005). Metode penelitian pendidikan. Bandung: Kerjasama Program Pascasarjana UPI dengan Remaja Rosdakarya.

Yee, N. (2002). Ariadne-understanding MMORPG addiction. New York: Mc Graw Hill Companies, Inc.

Yee, N. (2006). The demographics, motivations and derived eksperiences of users of massively-multiuser online graphical environments disorder. cyberpsychology \&, behavioral. Jurnal Psikologi, I(3), 237-244. 